\title{
John Rawls on redistribution and recognition
}

Pablo Aguayo (paguayo@derecho.uchile.cl) Facultad de Derecho, Universidad de Chile (Santiago, Chile) https://orcid.org/0000-0003-3239-5441

\begin{abstract}
In this paper, I argue that in the context of the redistribution-recognition debate, Rawls developed a theory of justice that exceeds the margins of allocative justice and has good arguments to deal with demands of social change and recognition. I propose that some criticism of the Rawlsian conception of social justice confuses allocative justice with distributive justice. In doing this, they not only understand Rawls's conception of primary goods as measuring staff, but they also reject their moral dimension. Finally, l examine the concepts of reciprocal recognition and self-respect to improve and expand the discussion about Rawlsian distributive justice.
\end{abstract}

Key words: allocative justice, distributive justice, reciprocal recognition, self-respect.

\section{Introduction}

It is a commonplace in discussions of contemporary political philosophy to hold that liberalism defends a normative conception of social justice characterised by blindness to differences. The belief that this blindness prevents liberals from recognising and giving just treatment to the demands of minority groups, is the basis on which has been constructed the grammar of social conflict developed by major authors over recent decades like Iris Marion Young, Nancy Fraser and Axel Honneth. Grounded on what I consider to be a false dilemma, these authors confront a conception of justice centred on recognition with one focused on distribution. Even though Young, Honneth and Fraser defend different paradigms, they all share the idea that conceptions centred on distributive justice are insufficient.

In this paper I show that underlying those approaches is a mistaken understanding of distributive justice, especially of the conception developed by John Rawls in A theory of justice. The core of this misunderstanding is the failure to distinguish between allocative justice and distributive justice. Once I have clarified that distinction, I shall defend the thesis according to which the conception of distributive justice defended by Rawls not only exceeds the margins of allocative justice but also offers sufficient arguments to meet the requirements of recognition. In this sense, my philosophical exercise is heading in a direction directly opposed to the recommendations made by Iris Marion Young in Justice and the politics of difference when she declared that "the concept of distribution should be limited to material goods" (Young 1990:8). By displacing the Distributive Paradigm, these authors not only restrict to a strictly economic question Rawls's conception of primary goods, but they also fail to grasp the moral and political perspective of his project, a perspective firmly based on reciprocal recognition and self-respect. 


\section{The recognition-theoretical turn}

Numerous turns have characterised the development of philosophy over recent decades. For example, the linguistic turn, the hermeneutic turn, the pragmatic turn, among others. Following Honneth, we can hold that one of the latter is "the recognition-theoretical turn" (Honneth 1995:111). This turn would be justified by the inability of the liberal model of distribution to deal with the claims of recognition made by a not insignificant number of social actors. The thesis of authors such as Taylor, Young, Honneth, and Fraser is that under the framework imposed by the grammar of distributive justice, it would be impossible to face those claims. The question of the grammar must be emphasised here, in fact Honneth's work The struggle for recognition is subtitled 'The moral grammar of social conflicts'. We cannot ignore the fact that a major component of grammar is semantics, that is to say, the study of the meaning of the terms constituting a language. In this sense, I want to show that the rejection of the grammar of distributive justice by defenders of politics of recognition in great measure stems from a confused understanding of the aim of distributive justice, at least with regard to the use of them in the context of the Rawlsian moral philosophy.

Let us consider, for example, the use Nancy Fraser makes of these notions in Redistribution or recognition. Fraser not only treats the notions of distribution and redistribution interchangeably, but also her understanding falls in the field of allocative justice. For Fraser the distributive dimension of justice "corresponds to the economic structure of society" (Fraser and Honneth 2003:50) which would be responsible for "the allocation of economic resources and wealth" (Fraser and Honneth 2003:50). In contrast to the above, for Rawls the central question of distributive justice was never how to allocate resources or goods, nor how to distribute them, but rather how to organise the basic structure of society. For Rawls the problem of distributive justice within the margins of his justice as fairness was to answer the question "how are the institutions of the basic structure to be regulated as one unified scheme of institutions so that a fair, efficient, and productive system of social cooperation can be maintained over time, from one generation to the next?" (Rawls 2001:50). This contrasts with the very different problem of "how a given bundle of commodities is to be distributed, or allocated, among various individuals whose particular needs, desires, and preferences are known to us" (Rawls 2001:50). Only this second problem is that of allocative justice.

Rawls categorically rejected the identification of his conception of distributive justice with the notion of an allocative justice, and even said that the central notion of allocative justice is "incompatible with the fundamental idea by which justice as fairness is organized" (Rawls 2001:50). In short, allocative justice would have efficiency as its aim, whereas distributive justice would seek fairness. Moreover, allocative justice conceives persons as merely rational, and rationality is always strategic rationality, whereas distributive justice conceives them to be rational, but subject to "reasonable constraints on the choice of principles" (Rawls 1971:13). For Rawls, understanding distributive justice as merely a question of allocation implies abandoning moral reflection on our reasons for preferring one general form of social organisation as opposed to another, or for defending a specific form of basic structure of society regulated by principles determining the fair distribution of social goods. The aim of Rawlsian distributive justice is the moral justification of the principles that regulate the basic structure of society and the practices that result from it. Seen in this light, it is clear that we will have problems if we fail to distinguish between the allocative and distributive dimension of social justice. If we think that the task of distributive justice is simply the allocation of resources, it will be extremely complex to take into consideration the claims for 
recognition made by different groups. Given the above, these claims would exceed the margins of such allocation. Questions of identity, dignity and status would not be resolved by distributive policies and, in this sense, I agree with Fraser and Honneth when they reject the economic vision that "reduces recognition to a mere epiphenomenon of distribution" (Fraser and Honneth 2003:2). But such rejection does not mean the Rawlsian conception of distributive justice cannot deal with the claims for recognition.

Moreover, if critics of the distributive paradigm take the line held by Young, according to whom it "tends to focus thinking about social justice on the allocation of material goods such as things, resources, income, and wealth" (Young 1990:15), then we should think seriously about the theoretical-philosophical sufficiency of this category to face the claims of the friends of recognition. However, as I hope to show here, the proposal developed by Rawls goes beyond the margins of allocative justice and the mere delivery of material goods. In fact, under the democratic interpretation Rawls makes of the principle of justice, we can consider that what should be maximised is the total index of primary goods. As is known, Rawls included in this list not only powers and opportunities, but also status and the social bases of self-respect, and even held that their distribution could be to the detriment of an increase in our income and wealth.

In a line of interpretation similar to Rawls, Samuel Freeman held that while least advantaged workers in a property-owning system may enjoy marginally less income than they would in the richest capitalist welfare state, they nonetheless "have greater powers and opportunities [...] These powers and opportunities are among the primary bases of self-respect in a democratic society" (Freeman 2007:107).

The last quotation from Freeman reinforces the idea that the conception of distributive justice defended by Rawls is not exhausted by the economic allocation of resources. Persons do not want to be merely recipients of goods, but also play an active role in the design and justification of their social institutions. In other words, what is at play here is how we conceive the justice of social practices, more than the justice of one particular case of allocation which would fall within one of these practices. On this point I can assert that Rawls would criticise all those who confuse allocative justice with distributive justice because "They fail to make the distinction between the justification of a practice and the justification of a particular action falling under it" (Rawls 1955:16). Two years later, in Justice as fairness, he states that the focus of distributive justice is on the social practices that determine our life in common. For Rawls justice must be understood as a virtue of institutions, "and not as a virtue of particular actions, or persons. Essentially justice is the elimination of arbitrary distinctions and the establishment, within the structure of a practice, of a proper balance between competing claims" (Rawls 1957:653).

In fact, Rawls insists that his principles should not be understood as principles of allocative justice, but as principles to regulate the basic normative structure. To achieve the latter, the question of reciprocal recognition between moral persons is fundamental and I shall go on to develop this point.

\section{The importance of reciprocal recognition for justice as fairness}

In his 1942 senior thesis $A$ brief inquiry into the meaning of sin and faith, Rawls offered a distinction that could be considered central as much for the future development of his moral conception of the person, as for the moral bases of his theory of justice as fairness. That distinction differentiated 
between (i) relationships established between objects in nature (called causal); relationships we establish with objects in nature (natural) and relationships we establish with other persons (personal and communal). The latter was characterised by the existence of a mutual respect and "by the recognition of the other as a thou" (Rawls 2009:115). The identification of the distinguishing features of the I-thou relationship implied the acceptance of one of the central notions forming Rawls's moral philosophy, namely the recognition of the other as unique and equal, with the same faculties and possibilities. In this way, some relevant issues for the architectonic of his moral philosophy, such as the fact of mutual recognition of the principles of justice, depends on this mutual recognition of the dignity of persons participating in them. Such recognition would be made possible by our moral powers, within which the sense of justice would hold a fundamental place.

However, this notion of recognition was important not only in his early thoughts on morality. In Justice as fairness he attributed great importance not only to the notion of reciprocal recognition, but also to the moral feelings that made possible the justification of the principles of justice.

From his earliest reflections Rawls identified a two-fold basis of his principles of justice. This twofold basis recognises, on the one hand, persons not concerned about the interests of others and motivated to reach an agreement that does not affect their benefits, and on the other hand, persons guided by moral feelings who tend towards moral recognition. Rawls developed these two methods for deriving the principles of justice in an unpublished work entitled The two-fold basis of justice (hereafter TFB, available at Box 9, Folder 1, Harvard University Archives). In this work Rawls indicated that there are two ways in which to show that certain principles of justice should be accepted. Rawls called the first The Conventional Basis. The argument sketched for this basis held that the principles of justice: "are those principles for designing practices which persons (or other agencies) who meet one another in the situation of justice can agree upon. That is, they are principles which persons whose interests are egoistic with respect to one another can accept: for the principles of justice maintain an impartiality and an equality of treatment except where it is in the advantage of all to permit a difference" (Box 9, Folder 1).

Rawls called the second basis, on which the principles of justice could be founded, The Natural Basis. According to it, the principles of justice reflect: "the judgments of one whose aim it would be to care for all interests equally, to pay due attention to them all, and to take them all into account. Anyone who feels for the interests of others, indeed anyone who recognizes them as persons, and who is at the same time impartial between them, will judge that their interests should be treated equally, and differences be allowed only where it is to the advantage of every one's interests alike" (Box 9, Folder 1).

Rawls argued that any person showing empathy (or impartial sympathy) to the interests of others, or who recognised others as moral persons, would judge that their interests should be treated equally, and that differences would be allowed only when these granted reciprocal advantage to the interests of each individual. For him this natural basis "simply invokes the thought that morality, and in particular justice, is imbedded in the act of recognizing persons as persons: justice is the reciprocal recognition of persons as persons" (Box 9, Folder 1 ).

With respect to this natural basis of the principles of justice, Samuel Freeman claims that in the development of his thought Rawls seeks to discover "the fundamental moral principles that regulate reasoning and judgments about justice [...] Rawls here moves some way toward the more 
'sentimental' and 'naturalistic' accounts suggested by Rousseau and Hume" (Freeman 2003:2). In the same vein Priscilla Mackenzie maintained that "Rawls's choice to call this basis of justice 'natural' draws attention to his affirmation of a moral naturalism of sorts. Justice is rooted in the natural response of recognition to real persons in the world" (Mackenzie 2012:51).

\section{Taking persons seriously}

As we have just seen, Rawls also developed a conception of justice characterised by reciprocal recognition between moral persons understood as moral agents. For him, a liberal democratic understanding of justice must commit to a reciprocal treatment of the interests and expectations of persons as persons, but what does this mean in practice? What implications would there be in the adoption of the principles of justice for the design of a society based on reciprocal recognition? As we know Rawls is not thinking of principles for the design of society in general. The principles of justice must be applied in the first instance to the "basic structure of society" (Rawls 1968:61). This structure will include the political constitution and the principal economic and social institutions which taken as a whole, define nothing less than "a person's liberties and rights" (Rawls 1968:53).

The above is closely related to a question Rawls had already discussed in Justice as fairness and The sense of justice, namely the idea of having a morality and having moral powers. For Rawls, reciprocal recognition based on moral feelings such as a sense of justice plays a central role in the establishment of fair practices and, by extension, should be the basis for the moral justification of the principles of justice. We must not forget that for Rawls, having a morality made possible "forms of conduct by which participants in a common practice exhibit their recognition of each other as persons with similar interests and capacities" (Rawls 1958:181). However, not only the sense of justice relates to the moral basis Rawls seeks for his principles, but also this basis relates to the capacity to orient us in the search of our own good. Rawls considers that each person has a conception of what is good for them, a conception that is inevitably interwoven with our own expectations.

Those expectations would arise not only because they are part of society, but also a result of our effective participation in the different associations which we form. It is the recognition of these moral powers (of the sense of justice and the capacity we have to form, revise and rationally pursue our own good) that is at the basis of Rawlsian thought on how we should arrange the institutions of society in such a way that these take persons seriously. To take persons seriously would be to consider them to be free and equal moral persons. Only by treating them in this manner can we arrive at what Cohen thought of as "the ideal of a society that treats members as equal moral persons, irrespective of differences of class background and natural endowment" (Cohen 2003:99).

In relation to the above, Rawls claims that the best way to take people as moral persons is by the adoption of two principles of justice as the most adequate scheme for social organisation and the just distribution of social goods. With his democratic interpretation of the principles of justice, Rawls proposes not only taking on the inequalities arising out of the design of the basic structure of society, which would favour some over others, but also the very structure of the institutions and social practices.

Here we can see how Rawls, in contrast to Young's assertions, does have a particular preoccupation with the social structures by which inequalities are maintained. In Justice and the politics of 
difference, Young stated that the paradigm of distributive justice "inappropriately restricts the scope of justice, because it fails to bring social structures and institutional contexts under evaluation" (Young 1990:20). What is restricted is rather the breadth of understanding shown by Young to Rawlsian distributive justice.

In effect, for Rawls the principles of justice would be applied then with the intention of remedying the fact that some differences allow some benefits to be achieved arbitrarily. This is where we glimpse the answer to the question of the implications that the establishment and adoption of the principles of justice would have for the organisation of society. The institutions of society should be arranged in such a way that they avoid, to a large extent, the arbitrary inequalities produced by the natural or social distribution of competitive advantages, such as the inequalities to which we are exposed by our public and private preferences, or the way in which we carry out our plans of life.

\section{A Rawlsian approach to reciprocal recognition}

During this paper I have claimed that the allocation of economic resources and wealth do not exhaust the distributive requirements of the Rawlsian conception of social justice. I hope that this thesis has become clear. Only if we accept it, will it make sense to try to discuss the claims of recognition from what I have called the Rawlsian conception of reciprocal recognition. This conception hopes to be something more than a liberalism of tolerance or non-discrimination, it hopes to become a solid liberal conception to face the claims of recognition and the politics of difference that such claims involve.

There is no doubt that claims of recognitions are associated not only with claims of (formal) equality of treatment, but also with claims of mutual respect. In this sense, and if we pay attention to its etymology, respect is fundamentally a question of perception, it is a way of seeing, likewise selfrespect would be its reflective mode. However, every way of seeing is an interpretation, seeing something as something. In this way, self-respect depends on a self-perceptive interpretation within a perceptual framework. In the case of Rawls, the said framework must be supported by the basic structure of society and by the way in which this society organises social practices. In this sense, self-respect could be damaged not only because individuals fail to have appropriate thoughts and emotions with respect to themselves, but also because they lack an appropriate situation which allows them to support the construction of a basal framework for positive self-worth. In other words, under a system of unfair social practices it would only be possible to find an unfair distribution of social goods. This unfair distribution would not only negatively determine the life of every single person but would also hide and even deny their legitimate claims.

My thesis here is that the failure to recognise the legitimacy of these demands is a form of failure to recognise the dignity and the rights of persons. I am following Joel Feinberg here in The nature and value of rights when he maintained that: "To respect a person [...] simply is to think of him as a potential maker of claims [i.e., as someone who has rights]" (Feinberg 1970:252).

All the above would lead persons to lack confidence in the value of their plan of life, and a lack of confidence with respect to the means at their disposal to achieve their goals. In this vein, Rawls's proposal offers a line of argument to satisfy those claims under a conception of justice as fairness. Within such a conception the idea of self-respect and reciprocal recognition are central. 
As proof of the above assertion, in The basic liberties and their priority, Rawls asserted that the importance of self-respect is that it provides a secure sense of our own value, a firm conviction that our determinate conception of the good is worth carrying out. Thus, "the parties give great weight to how well principles of justice support self-respect, otherwise these principles cannot effectively advance the determinate conceptions of the good of those the parties represent [...] For our sense of our own value, as well as our self-confidence, depends on the respect and mutuality shown us by others" (Rawls 1981:33).

\section{Social bases of self-respect}

As we have seen, one of the central issues underlying the claims of recognition is the need to treat persons with equal respect and consideration. Only under these conditions of mutual recognition and respect will be possible to achieve sufficient self-respect to enable us to "pursue a preferred plan of life" (Rawls 1971:108). It is this relevance of self-respect that led Rawls to maintain that this "is perhaps the most important primary good" (Rawls 1971:396), a good that would lexicographically permit the placing in a hierarchy of the remaining goods. But what does Rawls understand by self-respect? Rawls characterised self-respect as having two aspects. In the first place, it implies the sense a person has of her own value, that is to say, her conviction that her conception of good, her plan of life, is worth carrying out. In the second place, self-respect implies the necessary confidence that my abilities are sufficient to advance the plan of life I have chosen and, moreover, that its achievement is worthwhile. In both aspects it is fundamental that our efforts are recognised and appreciated by those around us as, if this were not the case, it would be "impossible for us to maintain the conviction that they are worthwhile" (Rawls 1971:441). Thus, the relevance that recognition by our associates has -as much of our person (self-respect) as of our actions (self-esteem)- makes it difficult to think that Rawls wanted to defend an individualist conception of society as some authors have tried to suggest.

Such is the importance that self-respect plays in the argument of Rawls's theory of justice that he even said that without self-respect "nothing may seem worth doing, or if some things have value for us, we lack the will to strive for them. All desire and activity become empty and vain, and we sink into apathy and cynicism" (Rawls 1971:440). In other words, self-respect is one of the essential requisites in the determination of the identity of persons, an identity which is determined not by standards they have created, but by norms and criteria accepted by their associates. In this vein, Roberto Alejandro says: "the Rawlsian self is not so prior to its ends, after all. Its self-esteem is not anchored in values the self-derives from itself, but in values that its associates accept" (Alejandro 1993:79). It is for these reasons that our plan of life needs to be appreciated and confirmed by others.

The fact that self-respect is considered as perhaps the most important primary good is what converts it into one of the central elements of the justification of the principles of justice, that is to say, into one of the guiding ideas of Rawls's conception of justice. Seen from this viewpoint, selfrespect is considered as an essential component to enable people to freely pursue any conception of a good life, or to live as freely and equally as possible within a political society. In fact, Rawls even considered that self-respect could function as an index to determine the level of fairness and justice of a system of social practices. 


\section{Conclusion}

To sum up, the fact that persons seek to have self-respect plays a key role in the argument that leads the parties in the original position to choose Rawls's principles of justice. These principles would allow the organisation of the basic structure of society in such a way that my plan of life could be advanced, my abilities realised and my idea of good pursued. But as we have seen, self-respect is strongly determined by the type of relationship I establish with the other members of society and by the way in which they recognise, value, and respect myself. For Rawls "Self-respect is reciprocally self-supporting" (Rawls 1971:179). He defends the idea that for this to be possible, it cannot be merely a question of luck or individual responsibility. We must advocate a liberal theory of justice, which resting in the notion of fairness, distributes the social bases of self-respect as a matter of justice. Only if we achieve this, will it be possible to advancement of a diversity of kind of life by means of which each of us could carry out his plan of life.

\section{Note}

I am grateful to Chris Lyon for carefully reading a previous version of this paper and providing me with valuable comments. In addition, I am indebted to Priscilla Mackenzie for her kind collaboration with the manuscript about Rawls' moral psychology and Martin O'Neill for his invitation to present this paper in the Philosophy Seminar at York in 2019. This paper is part of the project FONDECYT No. 11170230.

\section{References}

Alejandro, R. (1993). Rawls's communitarianism. Canadian Journal of Philosophy, 23(1), 75-100. https://doi.org/10.1080/00455091.1993.10717311

Cohen, J. (2003). For a democratic society. In S. Freeman. The Cambridge companion to Rawls, pp. 86-138. Cambridge University Press.

Feinberg, J. (1970). The nature and value of rights. The Journal of Value Inquiry, 4, 243-257. https://doi.org/10.1007/BF00137935

Fraser, N., Honneth, A. (2003). Redistribution or recognition? A political-philosophical exchange. Verso.

Freeman, S. (2003). The Cambridge companion to Rawls. Cambridge University Press.

Freeman, S. (2007). Justice and the social contract. Essays on Rawlsian political philosophy. Oxford University Press.

Honneth, A. (1995). The struggle for recognition: the moral grammar of social conflicts. Polity Press.

Mackenzie, P. (2012). Personhood and the nature of morality in the early Rawls. Original paper delivered at Yale University, 30 Nov. 2012. https://www.yumpu.com/en/document/read/7694069/bok-earlyrawlspersonhood

Rawls, J. (1955). Two concepts of rules. Philosophical Review, 64(1), 3-32. http://doi.org/10.2307/2182230 
Rawls, J. (1957). Justice as fairness. Journal of Philosophy, 54(22), 653-662. https://doi.org/10.2307/2021929

Rawls, J. (1958). Justice as fairness. Philosophical Review, 67(2), 164-194. https://doi.org/10.2307/2182612

Rawls, J. (1968). Distributive justice: some addenda. Natural Law Forum, 13(1), 51-71. https://doi.org/10.1093/aji/13.1.51

Rawls, J. (1971). A theory of justice. Harvard University Press.

Rawls, J. (1981). The basic liberties and their priority. The University of Michigan.

Rawls, J. (2001). Justice as fairness: A restatement. Harvard University Press.

Rawls, J. (2009). A brief inquiry into the meaning of $\sin \&$ faith. Harvard University Press.

Young, I. (1990). Justice and the politics of difference. Princeton University Press.

Recibido el 9 Jun 2020

Aceptado el 24 Ago 2020 